\title{
Parents' Satisfaction on Children's Dental Care Received at the Kulliyyah of Dentistry, International Islamic University Malaysia
}

\author{
Nor Asilah Harun ${ }^{1}$, Noor Lide Abu Kassim², Sayfaldeen Muhannad Kashmoola ${ }^{3}$, Ahmad Badruddin bin Ghazali ${ }^{1}$ \\ ${ }^{1}$ Kulliyyah of Dentistry, International Islamic University Malaysia Kuantan. \\ ${ }^{2}$ Kulliyyah of Education, International Islamic University Malaysia Gombak. \\ ${ }^{3}$ Faculty of Dentistry, UiTM Sungai Buloh Campus, Selangor Darul Ehsan.
}

\begin{abstract}
Introduction: Part of the undergraduate training in dental school is treating dental patients under close supervision of trained supervisors. Islam emphasises the highest quality in service rendered. Aim: To evaluate parent's satisfaction with their children's dental care provided by undergraduate dental students at the Student Polyclinic, Kulliyyah of Dentistry (KOD), International Islamic University Malaysia (IIUM). Materials and Methodology: This is a cross-sectional descriptive study. A self-administered questionnaire with questions on accessibility and availability, physical environment, service quality, interpersonal communication, cost of treatment, efficacy and treatment outcome was distributed to parents whose children received dental treatment anytime January 2013 to October 2013. Data collected was analysed using the Independent Sample T-Test, and Mann-Whitney Test. Results: 70 questionnaires were completed and analysed. The results showed that the average level of parental satisfaction was high. The parents were most satisfied with students' interpersonal communication. The level of satisfaction of parents of female children is higher than parents of male children although the difference was not significant. No significant differences were found in relation to which parent accompanied the child for treatment and the parent's education level. However, the parent's level of satisfaction is associated with type of occupation, where non-health-related workers expressed higher level of satisfaction $(p<0.05)$. Conclusion: Parents were generally satisfied with the care that their children received, mainly with the aspect of students' interpersonal communication and physical environment of the clinic. The results also indicated that level of satisfaction is associated with the nature of the parent's occupation.
\end{abstract}

KEYWORDS: Parent's satisfaction, dental students, dental care

\section{INTRODUCTION}

Patient satisfaction is an important and commonly used indicator for measuring the quality in health care. The best possible health care can be measured by assessing the satisfaction of the patient. ${ }^{1}$ Patient satisfaction is defined as "meeting the patient's request" in the Workbook on SERVQUAL, Malaysia Ministry of Health, 2011. ${ }^{2-3}$ It is therefore essential to determine the patient satisfaction in the assessment of the quality of health service as satisfaction indicates whether the service truly fulfils the patient's request. ${ }^{4}$ Satisfactory service quality can be achieved when the service provided meets or exceeds the customers' expectations. Satisfaction assessment towards dental treatment received by patients is important to identify ways of improving the service, as a good predictor for the

Corresponding author:

Nor Asilah Harun

Kulliyyah of Dentistry, International Islamic University Malaysia, 25200 Kuantan, Pahang, Malaysia

Tel: +609-5705517, Fax: +6095705580

Email: norasilah@iium.edu.my patient compliance with the treatment and continuing visit and also a useful tool for assessing the clinical and communication models. ${ }^{5-6}$ Thus, the satisfaction assessment should not just assess the outcome of the treatment but also the process of the treatment.

Patients seek dental treatments to relieve dental pain, alleviate any dental problems, to obtain regular oral-health examinations and sustain dental function. Selection of dental clinics for their treatment is based on accessibility, convenience and affordability. While most dental clinics help solve the dental problems of the patients, dental teaching schools is also the preferred choice due to their reputation and affordability. ${ }^{7-8}$

In dental schools, students in the clinical year will be treating patients under close supervision of trained supervisors as part of their training. It is a major concern of the dental school to teach the students about providing good quality dental treatment to the patients. ${ }^{9-11}$ Islam emphasises the highest quality possible, especially in serving other people's needs and for those who require help, as 
narrated in the hadith by Al-Bukhari and Muslim: Whoever relieves a believer's distress of the distressful aspects of this world, Allah will rescue him from a difficulty of the difficulties of the Hereafter. The patient's feedback serves as an indicator for the assessment of the quality of service for future improvement.

The feedback from the patient is extremely important so that the quality of the service provided by the students can be assessed. Patient satisfaction is crucial because a patient who is satisfied shows better compliance, fewer unattended appointments, less anxiety, pain and perception because satisfaction promote physician-patient trustful relationship. ${ }^{12-13}$ This will also lead to a better flow of patients to the dental school for the students to accomplish their training before they graduate.

Complaints made by patients may cause a great deal of anxiety and stress among the students and the dental school. The success of an oral health service can be assessed by the degree of satisfaction of its patients. Questionnaires are used as a measurement tool for assessing satisfaction in service in most studies. In dentistry, two frequently used assessment tools for studying dental clinic users' satisfaction are the Dental Visit Satisfaction Scale (DVSS) and the Dental Satisfaction Questionnaire (DSQ). Multiple different dimensions are constructed in the questionnaire to represent the satisfaction elements of the patient. For Ministry of Health Malaysia, patient satisfaction is assessed using SERVQUAL which is conducted twice a year. However, assessment of the parents' satisfaction with dental care provided by dental students for their children at dental school is uncommon.

The aim of this questionnaire based study is to evaluate parent satisfaction following dental care provided to their children at the Student Polyclinic, Kulliyyah of Dentistry, International Islamic University of Malaysia.

\section{METHODS}

This cross-sectional descriptive study was approved by the Research Steering Committee of the KOD, IIUM. All parents of paediatric patients aged 4 to 14 years old who attended the Paediatric Dentistry clinical at the Student Polyclinic, KOD, IIUM from January 2013 to October 2013 were included in this research. Seventy parents of paediatric patients who received dental treatment from final year dental students were approached to participate in this study. Informed consent was taken and a selfadministered questionnaire was filled.

The questionnaire was in Bahasa Malaysia as all patients and their parents were able to understand the language. Content expert reviewed the questionnaire and it was validated for reliability by testing it on a random sample of 14 accompanied parents of patients attending the clinic prior to data collection. Reliability tests showed a Cronbach's alpha coefficient of 0.918 , indicating high internal consistency of responses.

The questionnaire was used to record the demographic information of respondents in addition to their level of satisfaction towards the dental care provided to their children by the dental students. Level of patient satisfaction was recorded using 28 questions, scored using a five point Likert scale ranging from 1 to 5 (Strongly Disagree, Disagree, Neither, Agree and Strongly Agree) for a total of six dimensions of satisfactions namely; accessibility and availability, physical environment, service quality, interpersonal communication, financial and, efficacy and outcome of the treatment. Parents were asked to evaluate their satisfaction towards dental care based on the dimensions listed in the questionnaire according to their observation and experience of their children. Parents of special needs patients and patients who are treated by specialists were excluded from the study. The age range of the patients is four to fourteen years old. Only patients who have started the dental care were included in this research, therefore first timer patients were excluded.

Data from the satisfaction questionnaire was tabulated using spread sheet software (Microsoft EXCEL 2010). Descriptive statistics were calculated for the individual questions and overall patient satisfaction and the data were analysed using Independent Sample T-Test, and Mann-Whitney Test. All statistical analyses were performed using SPSS-16 (SPSS; Chicago, IL, USA). A $p$-value of $<0.05$ was considered statistically significant.

\section{RESULTS}

A total of 70 parents consented to participate in the study. The mean age for the paediatric patients was 8.04 years (range from 4-13 years).

The mean overall parents' satisfaction score was 4.65. Table 1 indicates the mean for each dimension which revealed that the interpersonal has the highest score (mean=4.75).

Parents' satisfaction was measured in dimension: Interpersonal communication (Table 2), service quality (Table 3), efficacy and outcome of the

Table 1. Parents' satisfaction according to dimension

\begin{tabular}{lll}
\hline & Dimension & Mean \\
\hline D1 & Accessibility and availability & 4.43 \\
D2 & Physical environment & 4.68 \\
D3 & Service quality & 4.67 \\
D4 & Interpersonal communication & 4.75 \\
D5 & Financial & 4.74 \\
D6 & Efficacy and outcome of the & 4.64 \\
& Overall mean & 4.65 \\
\hline
\end{tabular}


treatment (Table 4) and accessibility and availability (Table 5). It was noticed that the majority of the parents were satisfied with interpersonal communication $(98.6 \%)$ and $100 \%$ of the parents agreed on the items about friendly attitude, appearance, willingness to help and good communication skill of the student (Table 2). Almost all of the patient agreed that the dental student were knowledgeable and know how to handle their children. $97.1 \%$ of them believed that their children were happy throughout the treatment (Table 3). None of the parents were unsatisfied with the care received and they were willing to bring back their children again $(97.1 \%)$ and even will recommended the clinic to other parents (98.6\%). However, $2.9 \%$ of parents were not satisfied with the appointment arrangement, clinic opening hours and appointment time (Table 5).
As showed in Table 6, independent Sample T-Test revealed no statistical difference in overall parents' satisfaction score between male and female children ( $p$-value $=0.276)$ and male and female respondents $(p$-value $=0.504)$. There was also no significant difference of satisfaction score between patients who have previous treatment under other dental clinics with a group of patients who have no such experience $(p$-value $=0.642)$, as well as patients who have been treated by a paediatric dental specialist with patients who have not been treated by any specialist ( $p$-value $=0.054)$. Parents' education levels show no statistically significant difference with the $p$-value $=0.108$. However, the Mann-Whitney Test was further used to analyse two different groups of parents' occupational nature, namely the non-health related group (mean $=3.90)$ and the health-related group (mean $=1.38$ ), and it showed that there is a significance difference between these groups ( $p$-value $=0.014)$.

Table 2. Interpersonal communication

\begin{tabular}{|c|c|c|c|c|c|}
\hline No & Item & $\begin{array}{l}\text { Disagree/strongly } \\
\text { Disagree } \\
\mathrm{n}(\%)\end{array}$ & $\begin{array}{l}\text { Neither } \\
\mathrm{n}(\%)\end{array}$ & $\begin{array}{l}\text { Agree } \\
\mathrm{n}(\%)\end{array}$ & $\begin{array}{c}\text { Strongly agree } \\
\mathrm{n}(\%)\end{array}$ \\
\hline 1. & $\begin{array}{l}\text { The dental student was friendly } \\
\text { and polite }\end{array}$ & 0 & 0 & $\begin{array}{l}21 \\
(30.0)\end{array}$ & $\begin{array}{c}49 \\
(70.0)\end{array}$ \\
\hline 2. & $\begin{array}{l}\text { The dental student appears neat } \\
\text { and clean }\end{array}$ & 0 & 0 & $17(24.3)$ & $\begin{array}{c}53 \\
(73.7)\end{array}$ \\
\hline 3. & $\begin{array}{l}\text { The dental student is always } \\
\text { willing to help }\end{array}$ & 0 & 0 & $\begin{array}{c}19 \\
(27.1)\end{array}$ & $\begin{array}{c}51 \\
(72.9)\end{array}$ \\
\hline 4. & $\begin{array}{l}\text { The dental student always } \\
\text { understand my child's needs }\end{array}$ & 0 & $\begin{array}{c}1 \\
(1.4)\end{array}$ & $\begin{array}{c}21 \\
(30)\end{array}$ & $\begin{array}{c}48 \\
(68.6)\end{array}$ \\
\hline 5. & $\begin{array}{l}\text { The dental student was } \\
\text { interested in attending my child }\end{array}$ & 0 & 0 & $\begin{array}{l}21 \\
(30.0)\end{array}$ & $\begin{array}{c}49 \\
(70.0)\end{array}$ \\
\hline 6. & $\begin{array}{l}\text { Dental student has good } \\
\text { communication skills with the } \\
\text { parent }\end{array}$ & 0 & 0 & $\begin{array}{c}18 \\
(25.7)\end{array}$ & $\begin{array}{c}52 \\
(74.3)\end{array}$ \\
\hline
\end{tabular}

Table 3. Service quality

\begin{tabular}{|c|c|c|c|c|c|}
\hline No & Ttem & $\begin{array}{l}\text { Disagree/strongly } \\
\text { Disagree } \\
\mathrm{n}(\%)\end{array}$ & $\begin{array}{l}\text { Neither } \\
\text { n (\%) }\end{array}$ & $\begin{array}{c}\text { Agree } \\
\mathrm{n}(\%)\end{array}$ & $\begin{array}{c}\text { Strongly agree } \\
\mathrm{n}(\%)\end{array}$ \\
\hline 1. & $\begin{array}{l}\text { The dental student examined my child } \\
\text { thoroughly }\end{array}$ & 0 & 0 & $\begin{array}{c}21 \\
(30.0)\end{array}$ & $\begin{array}{c}49 \\
(70.0)\end{array}$ \\
\hline 2. & $\begin{array}{l}\text { The dental student explained well about } \\
\text { the dental problem and the treatment } \\
\text { needed for my child }\end{array}$ & 0 & 0 & $\begin{array}{c}23 \\
(32.9)\end{array}$ & $\begin{array}{c}47 \\
(67.1)\end{array}$ \\
\hline 3. & $\begin{array}{l}\text { The dental student answered my } \\
\text { questions well }\end{array}$ & 0 & $(1.4)$ & $\begin{array}{c}23 \\
(32.9)\end{array}$ & $\begin{array}{c}46 \\
(65.7)\end{array}$ \\
\hline 4. & $\begin{array}{l}\text { The dental treatment for my child was } \\
\text { not painful }\end{array}$ & $\begin{array}{c}1 \\
(1.4)\end{array}$ & $(2.9)$ & $\begin{array}{c}25 \\
(35.7)\end{array}$ & $\begin{array}{c}42 \\
(60.0)\end{array}$ \\
\hline 5. & $\begin{array}{l}\text { My child was happy throughout the } \\
\text { treatment }\end{array}$ & 0 & $(2.9)$ & $\begin{array}{c}26 \\
(37.1)\end{array}$ & $\begin{array}{c}42 \\
(60.0)\end{array}$ \\
\hline 6. & $\begin{array}{l}\text { My child received good dental care from } \\
\text { the dental student }\end{array}$ & 0 & 0 & $\begin{array}{c}24 \\
(34.3)\end{array}$ & $\begin{array}{c}46 \\
(65.7)\end{array}$ \\
\hline 8. & $\begin{array}{l}\text { The dental student is knowledgeable and } \\
\text { disciplined }\end{array}$ & 0 & $\begin{array}{c}1 \\
(1.4)\end{array}$ & $\begin{array}{c}28 \\
(40.0)\end{array}$ & $\begin{array}{c}41 \\
(58.6)\end{array}$ \\
\hline 9. & $\begin{array}{l}\text { The dental student know how to handle } \\
\text { my child's behavior }\end{array}$ & 0 & $\begin{array}{c}3 \\
(4.3)\end{array}$ & $\begin{array}{l}30 \\
(42.9)\end{array}$ & $\begin{array}{l}37 \\
(52.9)\end{array}$ \\
\hline
\end{tabular}


Table 4. Efficacy and outcome of the treatment

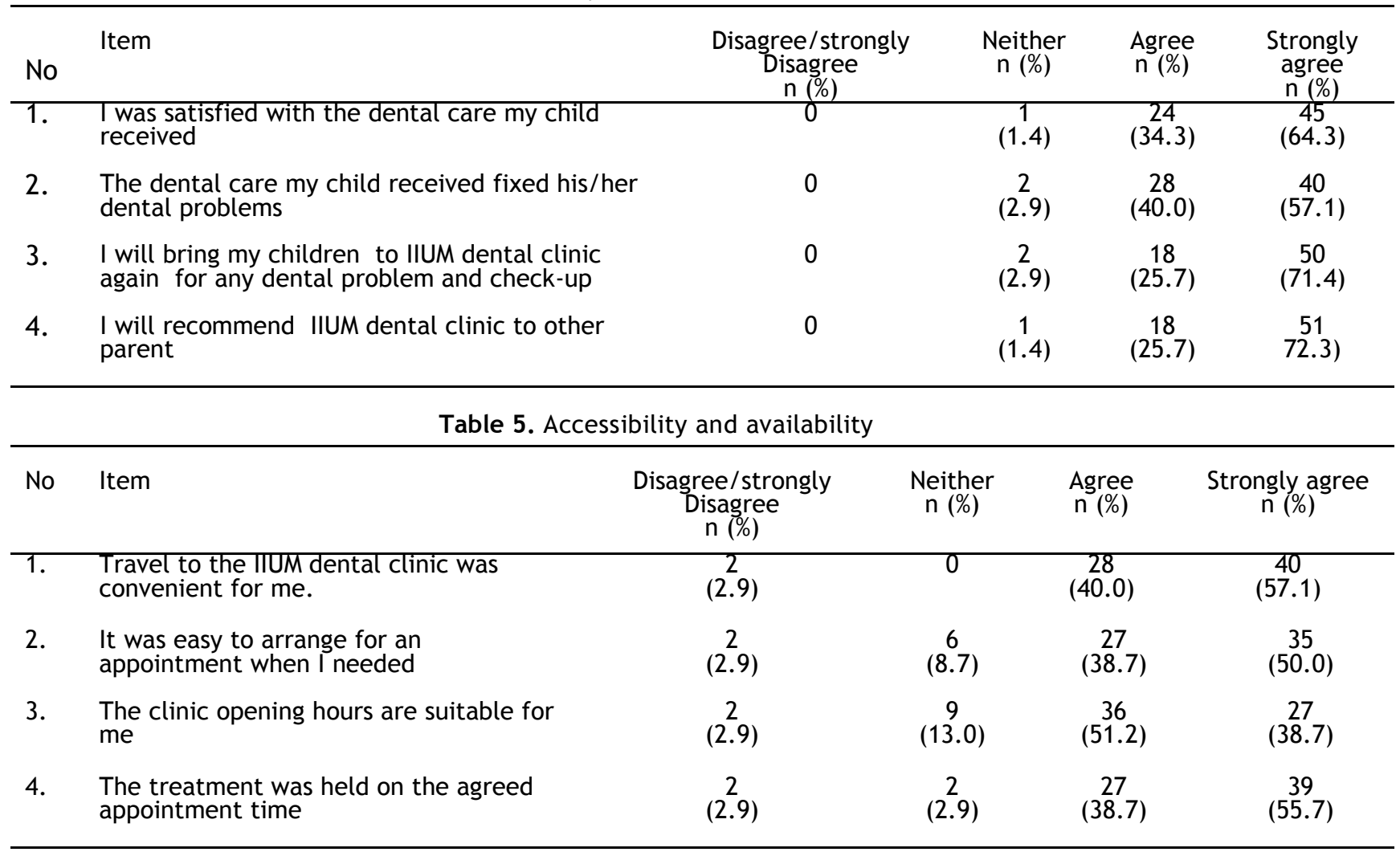

Table 6. Demographic characteristics of the respondents

\begin{tabular}{|c|c|c|c|c|c|}
\hline Demographic variable & & $\mathrm{n}$ & $\%$ & $\begin{array}{l}\text { Parents' satisfaction score } \\
\text { (mean) }\end{array}$ & $p$ value \\
\hline \multirow[t]{2}{*}{ Child gender } & Male & 33 & 47.14 & 3.56 & $0.276^{*}$ \\
\hline & Female & 37 & 52.86 & 4.14 & \\
\hline \multirow[t]{2}{*}{ Accompanying parents } & Father & 27 & 38.57 & 3.10 & $0.504^{*}$ \\
\hline & Mother & 43 & 61.43 & 4.06 & \\
\hline \multirow{2}{*}{$\begin{array}{l}\text { Had treatment at other clinics } \\
\text { before }\end{array}$} & Yes & 39 & 55.71 & 3.56 & $0.642^{*}$ \\
\hline & No & 31 & 44.29 & 4.00 & \\
\hline \multirow{2}{*}{$\begin{array}{l}\text { Had treatment with specialist } \\
\text { before }\end{array}$} & Yes & 11 & 15.71 & 2.80 & $0.054^{*}$ \\
\hline & No & 59 & 84.29 & 4.18 & \\
\hline \multirow[t]{2}{*}{ Parents' educational level } & $\begin{array}{l}\text { Secondary and } \\
\text { below }\end{array}$ & 43 & 61.43 & 3.62 & $0.108^{*}$ \\
\hline & $\begin{array}{l}\text { Tertiary and } \\
\text { above }\end{array}$ & 27 & 38.57 & 4.00 & \\
\hline \multirow[t]{2}{*}{ Parents' occupation } & Health related & 28 & 40 & 1.38 & $0.014^{\#}$ \\
\hline & $\begin{array}{l}\text { Non-health } \\
\text { related }\end{array}$ & 42 & 60 & 3.90 & \\
\hline
\end{tabular}




\section{DISCUSSION}

The present study has provided information about the parents' satisfaction with the dental care provided to their children by the clinical year dental students at the KOD, IIUM, Kuantan, Pahang, Malaysia. The number of respondents is 70 .

Patients' satisfaction is the primary aim of dental treatment and it becames a major concern in the treatment delivery system for health providers all over the world, ${ }^{14}$ particularly in the our setup as our establishment is an Islamic University which strives to provide the best quality of service. Islam commands Muslims to practice and apply Ihsan, striving for excellence, in all that they do. Ihsan is important in that it is obligatory or wajib. It has been mentioned in the Quran, where Allah the Almighty says in chapter 16, verse 90: "Indeed, Allah orders justice and good conduct and giving to relatives and forbids immorality and bad conduct and oppression. He admonishes you that perhaps you will be reminded."

Measuring the patient's satisfaction is an important tool to assess the success and quality of dental care delivered, making it vital. Patient satisfaction is complex and is related to the patient's personality, past experience, knowledge, expectations and also to the health care provider. ${ }^{15-17}$ In this study, a selfadministered questionnaire is the preferred tool owing to its simplicity, speed, efficiency and effectiveness in collecting the information and assessing the level of satisfaction. ${ }^{18}$

Providing success and good quality dental care is not just based on the high degree of technical skills and expertise but also the soft skills that the student needs to demonstrate during treatment sessions. The Ministry of Higher Education (MOHE), Malaysia has instructed all universities to implement the teaching of soft skills at undergraduate and postgraduate levels. ${ }^{19}$ Areas of soft skills in dental training programmes have been concentrated mainly on individual soft skill elements such as communication skills, critical thinking, teamwork, leadership, professionalism, life-long learning and entrepreneurship. ${ }^{20}$ While knowledge and technical skills can be imparted to the students in the regular dental school training programs, soft skills need effective involvement from the students themselves. Apart from the actual dental treatment, effective communication, ethical awareness and professionalism are important to achieve satisfaction of the patient ${ }^{21-22}$, and this is in line with the Islamic teaching that really emphasises the way communication should be practiced as mentioned in the Quran, where Allah the Almighty says in chapter 2, verse 83: "Do not worship except Allah; and to parents do good and to relatives, orphans, and the needy. And speak to people good [words] and establish prayer and give zakah." and in chapter 41, verse 34: "And not equal are the good deed and the bad. Repel [evil] by that [deed] which is better; and thereupon the one whom between you and him is enmity [will become] as though he was a devoted friend."

In this study, from the overall score, parents are generally satisfied with the treatment received by their children and the parents are highly satisfied with the interpersonal dimension, which includes communication skills and interpersonal relationship with parents and patient (Table 1). This shows that the interpersonal and communication skills of the students are at a high standard and the teachings and implementation of soft skills to the dental are carried out well. IIUM emphasises on Islamic input when teaching the dental students which includes good communication skills. Islam also provides a guideline in the arena of human communication ${ }^{23-24}$ and it has been implemented in the dental teaching program, as the mission of the kulliyyah is producing generations of dental professionals with leadership qualities imbued in Islamic values. This can be the evidence that the akhlaq and Islamic values through interpersonal communication skills of the students is highly praised by the parents.

In the current study, parents are less satisfied with the accessibility and availability dimension especially in clinic operational hours, appointment arrangement and appointment times. This result is similar with other previous studies. ${ }^{25}$ The clinic opened only during office hours from Monday to Friday and paediatric dentistry clinical sessions for the treatment of paediatric patients only took place once a week on the allocated day. The patient could not choose the date and time for the appointment according to their own free time as it was fixed according to the student timetable. This factor may lead to dissatisfaction of the parents. Treatment while dealing with children behaviour is always a challenge for dentists, especially the less experienced undergraduate student. The parents in this current study were less satisfied with the way the students handled their children's behaviour. The dental school needs to find a solution to address this issue, especially in improving the student skills on child behaviour management.

Educational level, age and ethnicity of the patients and whether the patient is a regular attender or not are known to affect the satisfaction level of the patients. ${ }^{26-27}$ From this study, generally the sociodemographic characteristics had no influence on the satisfaction of the parents except for the nature of the occupation of the parent whereby the non-health-related worker is more easily satisfied compared to the health-related worker. This is perhaps due to the health-related worker being more knowledgeable about dental care and their high expectations of dental care.

While past dental experience that the patient received from previous operators can be a related factor for satisfaction ${ }^{14}$, but not in this study. Even though a group of patients have an experience of being treated by the qualified dentist and paediatric dentist specialist, their parent's satisfaction was as 
high as with the group with no such experience with no statistical difference. This may indicate that the quality of care provided by the student under closed supervision is at par with the qualified dentist and even with specialists.

Although the present study is the first of its kind to be conducted in the KOD, IIUM, patient satisfaction with the treatment by the dental students is complicated and may need further research utilising a larger sample size and involve multiple disciplines of dentistry, and not just paediatric dentistry unit. Face to face interview is suggested to assess each dissatisfaction in detail for future improvement of the service. Future research could also investigate the views on satisfaction with oral care from the children themselves (aged nine years or over) to see how accurately the parents' evaluation reflected the views of their children. The information obtained could be used to help improve oral care for this population.

\section{CONCLUSIONS}

It can be concluded that the majority of parents who took part in this study were satisfied with the care that their children received from the dental students at the KOD, IIUM, mainly with the aspect of students' interpersonal communication and physical environment of the clinic. The results also indicated that level of satisfaction was associated with the nature of occupation.

\section{ACKNOWLEDGMENT}

We would like to thank all the participating patients and students for their participation also to Kulliyyah of Dentistry, IIUM Kuantan Campus, Malaysia for their enormous support to this study. The publication of this study was funded by IIUM RIGS16328-0492.

\section{REFERENCES}

1. Blendon RJ, Schoen C, Donelan K, et al. Physicians' views on quality of care: a fivecountry comparison. Health Aff 2001; 20:23343.

2. Ghazali RJM, Sababudin R, Esa N, et al. Workbook on SERVQUAL, KKM: patient satisfaction survey using SPSS. Kuala Lumpur: Institut Pengurusan Kesihatan. 2011.

3. Wensing M, Vedsted P, Kersnik J, et al. Patient satisfaction with availability of general practice: an international comparison. Int J Qual Health Care 2002; 14:111-18.

4. Powell G, Williams AM, Larsen K, et al. Coordinating primary health care: an analysis of the outcomes of a systematic review. Med J Aust 2008; 188(8 Suppl):S65-8.

5. Fitzpatrick R Surveys of patient satisfaction: IImportant general considerations. BMJ 1991; 302:887-9.

6. Awliya Wedad Y, Patient satisfaction with the dental services provided by the Dental College
King Saud University. Saudi Dent J 2003; 15:116.

7. Thanveer K, Krishan A, Hongal S Treatment satisfaction among patients attending a private dental school in Vadodara, India. J. Int Oral Health 2010; 2:33-44.

8. Macfarlane TV, Blinkhorn AS, Davies RM, et al. Factors associated with health care seeking behaviour for orofacial pain in the general population. Community Dent Health 2003; 20:20-6.

9. Al-Hussyeen AJ Factors affecting utilization of dental health services and satisfaction among adolescent females in Riyadh city. Saudi Dent J 2010; 22:19-25.

10. Hashim R Patient satisfaction with dental services at Ajman University, United Arab Emirates. Eastern Mediterr Health J 2005; 11:913-21.

11. Mahrous MS, Hifnawy T Patient satisfaction from dental services provided by the college of dentistry, Taibah University, Saudi Arabia. J Taibah Univ Med Sci 2012; 7:104-9.

12. Janssen $C$, Ommen $O$, Neugebauer $E$, et al. How to improve satisfaction with hospital stay of severely injured patients. Langenbecks Arch Surg 2007; 392:747-60.

13. Hojat M, Louis DZ, Maxwell K, et al. Patient perceptions of physician empathy, satisfaction with physician, interpersonal trust, and compliance. Int J Med Educ 2010; 1:83-7.

14. Merican MI, bin Yon R. Health care reform and changes: the Malaysian experience. Asia Pac J Public Health 2002; 14:17-22.

15. Bosmans J, Geertzen J, Dijkstra PU Consumer satisfaction with the services of prosthetics and orthotics facilities. Prosthet Orthot Int 2009; 33:69-77.

16. Palihawadana $D$, Barnes $B R$ The measurement and management of service quality in dental healthcare. Health Serv Manag Res 2004; 17:229-36.

17. Chang WJ, Chang YH. Patient satisfaction analysis: identifying key drivers and enhancing service quality of dental care. J Dent Sci 2013; 8:239-47.

18. Al-Abri R, Al-Balushi A Patient satisfaction survey as a tool towards quality improvement. Oman Med J 2014; 29(1):3-7.

19. Ministry of Higher Education. Module for development of soft skills for higher learning institutions in Malaysia, 2nd ed. Serdang: Universiti Putra Malaysia, 2006.

20. Gonzalez MA, Abu Kasim NH, Naimie Z. Soft skills and dental education. Eur J Dent Educ 2013; 17(2):73-82.

21. Hannah A, Millichamp CJ, Ayers KM A communication skills course for undergraduate dental students. J Dent Educ 2004; 68:970-7.

22. Sangappa SB Patient satisfaction in prosthodontic treatment: Multidimensional Paradigm. J Indian Prosthodont Soc 2012; 12:21-6.

23. Azad MAK Principle of human communication: islamic perspective. RA Appl Res. 2015; 
1(6):227-31.

24. Mohammed ASA, Tibekb SR, Endotc I The principles of Total Quality Management System in World Islamic Call Society. 6th International Forum on Engineering Education (IFEE 2012). Procedia Soc Behav Sci 2013; 102:325-34.

25. Hashim R Patient satisfaction with dental service at Ajman University, United Arab Emirate. East Mediterr Health J 2005; 11(56):913-21.

26. Tuominen R, Tuominen M Satisfaction with dental care among elderly Finnish men. Community dentistry and oral epidemiology, 1998, 26(2):95-100.

27. Pagnamenta R, Benger JR Factors influencing parent satisfaction in a children's emergency department: prospective questionnaire-based study. Emerg Med J 2008; 25:417-9. 
